\title{
Timeline of Belgian medical history
}

Ordering time to make the final outcome of history appear as 'natural' has been for a long time one of the main functions of national histories. Timelines were one of these hermeneutic tools that condensed this willingness to represent a 'neat' and tamed past. Reading them today can be frustrating as they often focus on political and event-driven history, where the historical narrative tries to show the contingency of the past. We asked the contributors of each chapter to propose five dates that were important for their topic. These are assembled here not in a thematic but in a chronological order. At first sight, this timeline appears puzzling. There is no ' 1796 ' when the French governance reorganised public health around two institutions: the civil hospitals and the welfare bureaus. Neither does it include '1841', the date of the foundation of the Royal Academy of Medicine of Belgium, or '1944', the voting of the Social Security Act, which laid the basis of Belgium's post-war system of health insurance. Instead, here are forty-five events that, we hope, will lead the reader down sometimes unexpected paths of Belgian medical history.

1803 Foundation of the Sisters of Charity of Jesus and Mary in Ghent, one of the major orders of female religious in Belgian healthcare (p. 68)

1820 Creation of the first institute for deaf girls in Brussels by Jozef Triest (p. 287)

1834 Foundation of the Medical Society of Ghent (p. 139)

1841 Creation of the Catholic Society of St Vincent de Paul (p. 210)

1849 Creation of the single degree of Doctor of Medicine, Surgery and Obstetrics (p. 177)

1849 Establishment of the Superior Health Council, a national commission of non-medical administrators tasked with 
supervising city planning and the construction of public buildings (p. 144)

1850 Adoption of the Mental Treatment Act (p. 286)

1857 Inauguration of the Hospice pour hommes aliénés in Ghent (known as the Guislain asylum) (p. 251)

1868 Miraculé Louise Lateau first displayed the (visible) wounds of Christ, the start of an intense debate among physicians and theologians (p. 79)

1870 First ovariotomy performed in Belgium (p. 43)

1874 Establishment of medical inspection of public schools in Brussels (p. 145)

1876 Law on medical education, introducing laboratory research into the curriculum (p. 185)

1879 A proposition to allow midwives to use forceps is rejected by the majority of members of the Royal Academy of Medicine (p. 34)

1884 Opening of the Stuyvenberg hospital in Antwerp (p. 250)

1884 Isala van Diest is the first female physician allowed to practise in Belgium (p. 37)

1888 The first debate in the Belgian medical press on the occurrence of hysteria among male soldiers (p. 44)

1894 Law on mutual aid societies introducing the regime of 'subsidised liberty' (p. 213)

1895 Health education becomes a compulsory part of the curriculum in both primary and secondary schools (p. 327)

1896 One of the first Lumière screenings in Belgium at the Galerie du Roi in Brussels (p. 334)

1903 Todd/Christy/Dutton Liverpool School of Tropical Medi-

-05 cine sleeping sickness expedition in the Congo Free State (p. 122)

1905 Production of the first clinical research and teaching films by Arthur van Gehuchten at the Catholic University of Leuven (p. 337)

1907 Foundation of the Catholic St Camille School for Nursing in Brussels (p. 71)

1910 Foundation of the School for Tropical Medical Medicine by royal decree (p. 123)

1910 The Dutch physician Pieter Eijkman published L'internationalisme médical, an overview of international medical organisations that includes three Belgian initiatives (p. 134) 
1911 Creation of the Service d'Assistance Médicale Indigène (SAMI) (p. 107)

1911 Opening of the provincial hygiene museum of Mons (p. 329)

1913 Foundation of the Bulletin de l'Association belge de Médecine sociale (p. 151)

1922 Foundation of the Belgian Society of Saint-Luc, a society for Catholic doctors (p. 72)

1927 Informal foundation of the International League for Educational Film (p. 341)

1930 Creation of the Fonds Reine Élisabeth pour l'Assistance aux Indigènes (FOREAMI) (p. 111)

1935 Opening of the new St-Pierre Hospital in Brussels, the first 'block' or 'tower hospital' in Belgium (p. 264)

1937 Premiere of Un ennemi public, the first nationally produced public health film by Henri Storck and the Belgian National League Against Tuberculosis (p. 334)

1948 INAMI/RIZIV, the Belgian system of health insurance, registered a deficit for the first time (p. 225)

1949 Ten-year development plan for the Congo (p. 120)

1957 Legal regulation of medical specialisation (p. 193)

1958 The world exhibition takes places in Brussels, with the Atomium as its icon, a breakthrough also for televised science (p. 322)

1961 Foundation of the Institute for Family and Sexuality Studies at the Catholic University of Leuven (p. 84)

1963 Creation of L'Equipe in Anderlecht, the first sector-based mental health service in Belgium (p. 298)

1963 Law 'Leburton', regulating the price setting of medical fees (p. 227)

1968 First professorship in family medicine at the University of Leuven (p. 195)

1985 Inauguration of the university hospitals CHU Sart-Tilman (Liège) and Gasthuisberg (Leuven) (p. 269)

1990 Partial depenalisation of abortion (p. 51)

1990 Adoption of the Act on the Protection of the Mentally Ill (Loi relative à la protection de la personne des malades mentaux) (p. 307)

1994 Foundation of the International Centre for Reproductive Health (ICRH) (p. 157)

1995 First government-led experiments with personal assistance budgets (p. 303) 